\title{
Letter to the Editor: The John Insall Award: No Functional Benefit After Unicompartmental Knee Arthroplasty Performed With Patient- specific Instrumentation: A Randomized Trial
}

\author{
Kartik Logishetty MRCS ${ }^{(1)}$, Gareth G. Jones FRCS (T\&O), Justin P. Cobb FRCS
}

To the Editor,

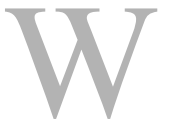

e read the award-winning paper by Ollivier and colleagues [5] with great interest. In their study, the authors concluded that patient-specific instrumentation (PSI) failed to deliver any clinical benefit in medial

(RE: Ollivier M, Parratte S, Lunebourg A, Viehweger E, Argenson JN. The John Insall Award: No functional benefit after unicompartmental knee arthroplasty performed with patient-specific instrumentation: A randomized trial. [Published online ahead of print March 20, 2015]. Clin Orthop Relat Res. DOI: 10.1007/ s11999-015-4259-0).

The authors certify that they, or any members of their immediate families, have no commercial associations (eg, consultancies, stock ownership, equity interest, patent/ licensing arrangements, etc) that might pose a conflict of interest in connection with the submitted article.

All ICMJE Conflict of Interest Forms for authors and Clinical Orthopaedics and Related Research ${ }^{\mathbb{R}}$ editors and board members are on file with the publication and can be viewed on request.

The opinions expressed are those of the writers, and do not reflect the opinion or policy of $C O R R^{\mathbb{R}}$ or The Association of Bone and Joint Surgeons ${ }^{\circledR}$. unicompartmental knee arthroplasty (UKA). We applaud their well-designed study, but offer an alternative interpretation of the results.

Prosthesis alignment was equally good in both the PSI and conventional instrumentation arms, leading the authors to conclude that "PSI does not provide better component positioning accuracy in frontal or sagittal planes" and that "PSI in UKA does not confer any substantial advantage in function after UKA" [5]. However, the two operating surgeons in this study perform more than 200 medial UKAs per year. We prefer the conclusion that PSI reliably replicates the radiological and functional results of expert surgeons.

UKA is a demanding procedure, requiring skill and experience to gauge device placement and soft tissue tension, with the best results coming from higher volume surgeons $[2,4,6]$.

K. Logishetty MRCS (凶),

G. G. Jones FRCS (T\&O),

J. P. Cobb FRCS

MSk Labs, Imperial College London,

London SW7 2AZ, UK

e-mail: k.logishetty@imperial.ac.uk
Indeed, the authors of this study have been performing UKA for more than 20 years [1]. PSI places different demands upon the surgeon compared to conventional UKA: A three-dimensional plan has to be made, approved, and then carried out. In our experience, the impact of planning surgery and then using technology to achieve that plan enables the inexperienced surgeon to achieve results that are comparable with an expert in other fields of arthroplasty [3]. Ollivier and colleagues [5] have confirmed this observation for UKA, albeit only in expert hands. The real challenge for this promising technology comes from its application in non-expert hands: PSI will show its real value when it makes the low-volume surgeon as good as the senior authors of this paper. That study should also win prizes.

\section{References}

1. Argenson JN, O'Connor JJ. Polyethylene wear in meniscal knee replacement. A one to nine-year retrieval analysis of the Oxford knee. 
J Bone Joint Surg Br. 1992;74:228232.

2. Badawy M, Espehaug B, Indrekvam $\mathrm{K}$, Havelin LI, Furnes O. Higher revision risk for unicompartmental knee arthroplasty in low-volume hospitals. Acta Orthop. 2014;85:342347.

3. Cobb JP, Kannan V, Dandachli W, Iranpour F, Brust KU, Hart AJ. Learning how to resurface cam-type femoral heads with acceptable accuracy and precision: The role of computed tomography-based navigation. J Bone Joint Surg Am. 2008;90 Suppl 3:57-64.

4. Hernigou P, Deschamps G. Alignment influences wear in the knee after medial unicompartmental arthroplasty. Clin Orthop Relat Res. 2004;423:161-165.

5. Ollivier M, Parratte S, Lunebourg A, Viehweger E, Argenson JN. The John Insall Award: No functional benefit after unicompartmental knee arthroplasty performed with patient-specific instrumentation: A randomized trial. [Published online ahead of print March 20, 2015]. Clin Orthop Relat Res. DOI: 10.1007/s11999-015-42590.

6. Zambianchi F, Digennaro V, Giorgini A, Grandi G, Fiacchi F, Mugnai R, Catani F. Surgeon's experience influences UKA survivorship: A comparative study between all-poly and metal back designs. Knee Surg Sports Traumatol Arthrosc. 2015;23: 2074-2080. 